\title{
RECONCILIATION AND VIOLENCE: HANNAH ARENDT ON HISTORICAL UNDERSTANDING
}

\section{INTRODUCTION}

A distinction frequently used to be drawn between Hannah Arendt's work as a political philosopher and as a historically-minded critic of political culture. ${ }^{1}$ Recently, however, scholars have stressed continuities between the historical focus of The Origins of Totalitarianism (1951) and the philosophical tenor of her later writings. ${ }^{2}$ Arendt has come to be seen as a thoroughly historical thinker, if not a historian. Yet her writings from the early 1950s, in which she constructed a historical sensibility grounded in readings of Marx and Hegel, have mostly been ignored. In these writings - part of an ambitious, unfinished book project entitled "Totalitarian Elements of Marxism" - she sought to identify aspects of Marxism that had hastened the emergence of totalitarianism, without condemning Marx's thought in its entirety. ${ }^{3}$ The result was a series of investigations into the philosophy of history that formed the basis for many subsequent articles and monographs. ${ }^{4}$ While some aspects of these writings - her critique of Marx, notion of ideology, and developing political theory have been examined, little has been said about the notion of history with which she tied them together. ${ }^{5}$ This essay will show that Arendt's notion of historical understanding centred on an uneasy relationship between the need for reconciliation

\footnotetext{
* For their comments on earlier drafts of this article, I would like to thank Ronald Beiner, Melissa Lane, Samuel Moyn, Christopher Ro, Martin Ruehl and the anonymous readers for MIH. I have also benefited from numerous discussions with Giovanni Menegalle.

${ }^{1}$ While The Origins of Totalitarianism (1951) has been taken to exemplify Arendt's historical bent, The Human Condition (1958) has been treated as a move to a form of republicanism in the civic humanist tradition, concerned above all with public speech and action and political freedom. For a discussion of this divide in Arendt scholarship see Richard H. King and Dan Stone, "Introduction", in Hannah Arendt and the Uses of History: Imperialism, Nation, Race, and Genocide, ed. Richard H. King and Dan Stone (Oxford, 2007), 5-6.

${ }^{2}$ Pivotal in eroding this separation have been the numerous essays collected in King and Stone, Hannah Arendt and the Uses of History; See also Karuna Mantena, "Genealogies of Catastrophe: Arendt on the Logic and Legacy of Imperialism", in Politics in Dark Times: Encounters With Hannah Arendt, ed. Seyla Benhabib (Cambridge, 2010).

${ }^{3}$ Hannah Arendt, "Project: Totalitarian Elements in Marxism" Project Outline (1951), Washington D.C., Library of Congress, Arendt Papers, Box 64 (hereinafter cited as LoC); Hannah Arendt to H.A. Moe, 29 Jan. 1953, LoC/Washington, Box 22, 012641.

${ }^{4}$ The chapter on Marx in The Human Condition, for example. Hannah Arendt, The Human Condition (Chicago, 1998), 79-136.

${ }^{5}$ For the most comprehensive study of these writings, see Margaret Canovan, Hannah Arendt: A Reinterpretation of Her Political Thought (Cambridge, 1994); See also Bhikhu Parekh, "Hannah Arendt's Critique of Marx", in Hannah Arendt: The Recovery of the Public World, ed. Melvyn A. Hill (New York, 1979).
} 
with the past, and a thorough rejection of twentieth-century violence. Her later attempts to theorise forms of judgment and action that avoided voluntarism and fatalism can be better understood in this light.

"Totalitarian Elements of Marxism" was a continuation of Arendt's endeavour to comprehend the emergence of the "idea of humanity". In Origins she had described the contribution of "race-imperialism" to the collapse of the nation-state and the international order. Race-imperialism along with antisemitism had enabled the totalitarian assault on human diversity and the unforeseen recognition of a common humanity. ${ }^{6}$ In her Marx project she extended this global and historical focus, treating the rise of labour, "the social" and the eclipse of the public sphere as preconditions for totalitarianism. ${ }^{7}$ The categories of labour and work, she argued, grounded modern historical consciousness. Marx's interpretation of the Hegelian philosophy of history emerged from this background, mandating the violent transformation of humanity in accordance with a teleology grounded in the emancipation of labour. ${ }^{8}$ In refining her theory of totalitarianism, she specified how particular political constructions of temporality could justify violence.

In grappling with the significance of totalitarianism, Arendt articulated a concept of reconciliation as a way of dealing with the worst of human experience. ${ }^{9}$ Moralistic forms of understanding that elicited straightforward condemnations, or comprehended concentration camps through precedents such as slavery - something

\footnotetext{
${ }^{6}$ Hannah Arendt, The Origins of Totalitarianism, (New York, 1951), 121-302; Hannah Arendt, "Organized Guilt and Universal Responsibility", in Essays in Understanding, 1930-1954: Formation, Exile, and Totalitarianism, ed. Jerome Kohn (2005), 131; For the international dimensions of Arendt's thought, see Patricia Owens, Between War and Politics: International Relations and the Thought of Hannah Arendt (Oxford, 2009); Robert Fine, Political Investigations: Hegel, Marx, Arendt (London, 2001), 151-65.

${ }^{7}$ Hannah Arendt, "Concern With Politics in Recent European Philosophical Thought", in Essays in Understanding, 1930-1954: Formation, Exile, and Totalitarianism, ed. Jerome Kohn (New York, 2005); Hannah Arendt, "Dream and Nightmare", in Essays in Understanding, 1930-1954: Formation, Exile, and Totalitarianism, ed. Jerome Kohn (New York, 2005); Hannah Arendt, "Europe and the Atom Bomb", in Essays in Understanding, 1930-1954: Formation, Exile, and Totalitarianism, ed. Jerome Kohn (New York, 2005).

${ }^{8}$ Hannah Arendt, "The Impact of Marx" (lecture notes), Washington D.C., Library of Congress, Hannah Arendt Papers, Box 68.

${ }^{9}$ For discussions of Arendt's notion of reconciliation, see Roger Berkowitz, "Bearing Logs on Our Shoulders: Reconciliation, Non-Reconciliation, and the Building of a Common World", Theory \& Event 14.1 (2011); Roger Berkowitz, "The Angry Jew Has Gotten His Revenge": Hannah Arendt on Revenge and Reconciliation", Philosophical Topics 39.2 (2011); Shai Lavi, "Crimes of Action, Crimes of Thought: Arendt on Reconciliation, Forgiveness, and Judgment", in Thinking in Dark Times: Hannah Arendt on Ethics and Politics, eds., Roger Berkowitz, Thomas Keenan and Jeffrey Katz (New York, 2009); Daniel and Birgit Maier-Katkin, "Hannah Arendt and Martin Heidegger: Calumny and the Politics of Reconciliation", Human Rights Quarterly 28.1 (2006): 86-119; Andrew Schaap, "Guilty Subjects and Political Responsibility: Arendt, Jaspers and the Resonance of the 'German Question' in Politics of Reconciliation”, Political Studies 49.4 (2001): 749-66.
} 
she attributed to contemporary social scientific analyses - prevented a confrontation of the 'elements' of totalitarianism in Western society. Something akin to a Hegelian mode of reconciliation to the world, discerning hermeneutic value in even the most appalling of events, might lead to a productive understanding of the past. But it might also create a fatalistic resignation in the face of historical events, or worse, support the Marxist view that past violence was the necessary 'midwife of history'. ${ }^{10}$ Two commitments were required to supplant Hegelian and Marxist responses to the past: firstly, to abandon a view of history as possessing rationality. To prevent this leading to a nihilistic politics of will or abandonment of oneself to the flow of history required a second commitment, to judging the past. This tied a concept of reconciliation to that of non-reconciliation.

Constructed at a time when she still felt totalitarianism to be an immediate threat, Arendt's notion of non-reconciliation was a blunt precursor to her theory of judgment. Non-reconciliation entailed a refusal of political arrangements founded on violence and a starting point for political action. It also conflicted with the need for reconciliation. Because Arendt viewed modern history and politics as overwhelmingly characterised by violence, the notion of non-reconciliation encouraged her to lay out extremely demanding sets of conditions for political legitimacy. This would feed into her ultimately implausible account of the quasi-contractual conditions for legitimate polities in On Revolution (1963). Many of the paradoxes of Arendt's later political thought stemmed from this relationship between violence and history.

This essay reinterprets several major aspects of Arendt's trajectory in the years following the publication of Origins in 1951. Though there have been numerous scholarly treatments of her historical thought as a form of 'storytelling', they have neglected the philosophical and anthropological justifications she provided for her historical approach. ${ }^{11}$ This essay examines these justifications in three ways. First, it

\footnotetext{
${ }^{10}$ Hannah Arendt, "Understanding and Politics", in Essays in Understanding, 1930-1954: Formation, Exile, and Totalitarianism, ed. Jerome Kohn (New York, 2005), 287.

${ }^{11}$ Joanna Vecchiarelli Scott, "Storytelling", History and Theory 50.2 (2011): 203-09; George Cotkin, "Illuminating Evil: Hannah Arendt and Moral History", Modern Intellectual History 4.3 (2007): 46390; Lynn R Wilkinson, "Hannah Arendt on Isak Dinesen: Between Storytelling and Theory", Comparative Literature 56.1 (2004): 77-98; Lisa J Disch, "More Truth Than Fact: Storytelling as Critical Understanding in the Writings of Hannah Arendt", Political Theory 21.4 (1993): 665-94; Seyla Benhabib, "Hannah Arendt and the Redemptive Power of Narrative", Social Research 57.1 (1990): 167-96; Ned Curthoys, "Hannah Arendt and the Politics of Narrative", Journal of Narrative Theory 32, 3 (2002): 348-70; Kai Evers, "The Holes of Oblivion: Arendt and Benjamin on Storytelling in the Age of Totalitarian Destruction", Telos 132 (2005): 109-20; Annabel Herzog, "Illuminating Inheritance: Benjamin's Influence on Arendt's Political Storytelling”, Philosophy \& Social Criticism 26.5 (2000):
} 
examines the historical dimensions of her writings on imperialism and totalitarianism, showing that her critique of instrumental conceptions of politics emerged from a critique of historically-grounded justifications of violence.

Second, it shows that though Marx was an important figure in Arendt's intellectual development in the early 1950s, he was a starting point for a number of concerns, rather than her sole interest. Uninterested in producing a straightforward antitotalitarian take on Marx, she used parts of his political economy to ground her depiction of the rise of 'mass' societies. Such societies, she argued, fostered alienated and instrumental attitudes towards the world, and a search for meaning through the direction of historical change. This led to politics based on practices of violent domination and legitimised with reference to the course of history. Her reading was shaped by French thinkers such as Alexandre Kojève, Jean-Paul Sartre and Maurice Merleau-Ponty. ${ }^{12}$ Connecting these concerns to her critique of the nihilism of French existentialism and the relationship between violence and history in Marxism shows how sustained these reflections were, casting light on the transition from her earlier work to later criticisms of Sartre and Frantz Fanon in On Violence (1970), and her condemnation of the Vietnam War. ${ }^{13}$

Third, this essay shows that by 1954, Arendt had developed a positive notion of historical understanding, defined against Hegelian reconciliation to the past. A central foil for this, as with her examination of violence, was French existentialist thought specifically that of Sartre and Merleau-Ponty - which she felt failed to grasp the unprecedented historical situation. Against their purported combination of voluntarism and fatalism, she sought a means of interpreting the past that was reconciled to the impossibility of political action reliably realising its original intentions, but avoided nihilistic resignation to violent conflict.

Examining these three themes sheds light on the postwar intersection between German and French thought on history and violence, and revises interpretations of

1-27; Lynn R Wilkinson, "Hannah Arendt on Isak Dinesen: Between Storytelling and Theory", Comparative Literature 56.1 (2004): 77-98.

${ }^{12}$ For a rare discussion of Arendt in a French context see Jeffrey C Isaac, Arendt, Camus and Modern Rebellion (London, 1992), 82-83; Another exception to this is Ned Curthoys's discussion of Arendt's critique of violence in the context of debates among French intellectuals about the French-Algerian war. See Ned Curthoys, "The Refractory Legacy of Algerian Decolonization: Revisiting Arendt on Violence", in Hannah Arendt and the Uses of History: Imperialism, Nation, Race, and Genocide, ed. Richard H King and Dan Stone (Oxford, 2007).

${ }^{13}$ Hannah Arendt, On Violence (New York, 1970); Hannah Arendt, "Home to Roost", in Responsibility and Judgment (New York, 2009); Owens, Between War and Politics, 150. 
Arendt as a historical thinker. It also points to the origins of her later theory of judgment. This essay begins by considering Arendt's writings on imperialism and totalitarianism and critique of French existentialism. It then turns to her articulation of reconciliation and non-reconciliation as ways with which to comprehend the past with an eye to responsible political action, before showing how this approach inflected her investigations of labour, history and - crucially - violence.

\section{IMPERIALISM, NIHILISM AND HISTORY}

A history of modernity and critique of violence as much as an investigation of Marxism, "Totalitarian Elements of Marxism" possessed significant continuities with Arendt's earlier work. In particular, the account of race-imperialism that came to form a central part of Origins shows that from an early stage she saw violence as a central "subterranean" element of Western history. ${ }^{14}$ Imperial expansion tied to racial domination, Arendt argued, had undermined the European nation-state by radicalising tensions between the state as impartial guarantor of rights, and the nation as ethnic community. ${ }^{15}$ Competition for scarce colonial outlets for capital generated conflict, leading to the collapse of the international state-system in war. ${ }^{16}$ As nation-states collapsed, totalitarian movements exploited the political vacuum, drawing on violent practices of racial domination developed in the colonies. ${ }^{17}$ This was her "boomerang thesis" - based on a reading of liberal J.H. Hobson - of the effects of colonialism on the legal and political structures of European states. ${ }^{18}$ Theories of ethnic supremacy justifying colonialism abroad undermined the concept of an impartial state at home. Despite debts to Rudolf Hilferding, Rosa Luxemburg and Lenin in describing the connections between capital accumulation, overseas expansion and war, Arendt's

\footnotetext{
${ }^{14}$ Even in late 1947, Arendt still referred to Origins as "her imperialism book". Hannah Arendt to Karl Jaspers, 4 Sept. 1947, Lotte Köhler and Hans Saner (eds.) Hannah Arendt and Karl Jaspers: Correspondence: 1926-1969, trans. Rita and Robert Kimber (New York, 1992), 96-99; Elisabeth Young-Bruehl, Hannah Arendt: For Love of the World (London, 1983), 203; Arendt used the term "subterranean" in the preface to the first edition of Origins. See Arendt, Origins, ix.

${ }^{15}$ Hannah Arendt, "Race-Thinking Before Racism", The Review of Politics 6.1 (1944), 36-73; Hannah Arendt, "Power Politics Triumphs", in Essays in Understanding, 1930-1954: Formation, Exile, and Totalitarianism, ed. Jerome Kohn (New York, 2005); Hannah Arendt, "Imperialism, Nationalism, Chauvinism", Review of Politics 7.4 (1945), 441-63; Hannah Arendt, "Expansion and the Philosophy of Power", The Sewanee Review (1946), 601-16; Arendt, Origins, 267-302.

${ }^{16}$ Arendt, "Imperialism, Nationalism, Chauvinism", 450; Arendt, "Expansion and the Philosophy of Power" 604-16.

${ }^{17}$ Arendt, "Imperialism, Nationalism, Chauvinism", 441-42.

${ }^{18}$ Hannah Arendt, The Origins of Totalitarianism, trans. E.B. Ashton 3rd edn. (London, 1967), 328; Ibid. 124, 126, 135; Mantena, "Genealogies of Catastrophe: Arendt on the Logic and Legacy of Imperialism".
} 
analysis lay well outside the paradigm of early twentieth-century Marxism, providing little detailed economic explanation of the influence of colonialism on European genocide. ${ }^{19}$ She was engaging in cultural criticism as much as history. For example, in her 1946 article "Imperialism and Suicide", she argued that the force behind European power-politics and imperialism lay in a scientific materialism that found man's origin in "Nothingness...in spiritually void matter", and therefore "looked toward the annihilation of man". Although driving the lust for power and possession, nihilism also catalysed the fulfillment of these desires in destruction, "the most radical form of domination as well as possession". ${ }^{20}$

Arendt's account of imperialism, while avowedly anti-colonial, was strongly Eurocentric, with implications for the inclusiveness of her understanding of history. ${ }^{21}$ She clearly possessed many of the prejudices of her contemporaries. ${ }^{22}$ In Origins she described sub-Saharan Africans as "without a culture or history of their own" for failing to erect a "human artifice" atop the natural world. ${ }^{23}$ The silence of indigenous peoples in her narrative of imperialism is compounded by empathetic descriptions of the experiences of European settlers and adventurers, who, when they killed, they were "not aware they had committed murder". ${ }^{24}$ Her Eurocentric cultural anthropology points to an uneasy early relationship to Hegel. Despite her claim in Origins that he was "never interested in the rise and fall of cultures as such or in any law which would explain the death of nations", Hegel did in fact pronounce judgment on peoples such as the North American Indians, and advocated colonisation to bring

\footnotetext{
${ }^{19}$ Arendt, Origins, 148-9, 168, 308; Rudolf Hilferding, Finance Capital: A Study of the Latest Phase of Capitalist Development, ed. T. B. Bottomore trans. Morris Watnick and Sam Gordon (London, 1910); Rosa Luxemburg, The Accumulation of Capital (London, 1913); Vladimir Ilyich Lenin, Imperialism: The Highest Stage of Capitalism (New York, 1916); For a discussion of Arendt's debts to other thinkers in Origins see Alfons Söllner, "Hannah Arendt's The Origins of Totalitarianism in its original context", European Journal of Political Theory 3.2 (2004), 230-35; While adopting its general tenor in Origins, Arendt in fact took little interest in the details of the Marxist analysis of imperialism. See Roy T Tsao, "The Three Phases of Arendt's Theory of Totalitarianism", Social Research 69.2 (2002), 583.

${ }^{20}$ Hannah Arendt, "Imperialism: Road to Suicide”, Commentary 1 (1946), 33.

${ }^{21}$ See, for example Tony Barta, "On Pain of Extinction: Laws of Nature and History in Darwin, Marx, and Arendt", in Hannah Arendt and the Uses of History: Imperialism, Nation, Race, and Genocide, ed. Richard H King and Dan Stone (Oxford, 2007) 87-108; Robert Bernasconi, "When the Real Crime Began: Hannah Arendt's the Origins of Totalitarianism and the Dignity of the Western Philosophical Tradition", in Hannah Arendt and the Uses of History, ed. King and Stone, 54-67; Mantena, "Genealogies of Catastrophe: Arendt on the Logic and Legacy of Imperialism".

${ }^{22}$ Richard H King, "On Race and Culture: Hannah Arendt and Her Contemporaries", in Politics in Dark Times: Encounters With Hannah Arendt, ed. Seyla Benhabib (Cambridge, 2010), 116.

${ }^{23}$ Arendt, Origins, 186, 300.

${ }^{24}$ Ibid., 192.
} 
Oriental peoples into the stream of real history. ${ }^{25}$ Though plausibly ignorant of these views, Arendt's analysis similarly implied the exclusion of peoples from history on the grounds of their purported inability to humanise the world; in her case through establishing laws, polities or written records of deeds. ${ }^{26}$ This was a spatially and temporally understood differentiation between humanist and quasi-natural relationships to the world that would shape her later distinction between work and labour.

Despite condemning imperialism more for its effects on Europe rather than the non-European world, Arendt rejected the idea that the barbarism of totalitarian rule was only an import from colonial encounters. The bureaucratised violence of colonial practices was a product of a nihilism that unfolded from the heart of Western thought. ${ }^{27}$ By the end of 1946, she had dropped the idea of violence as an immediate relation between consciousness and the world, as described in "Imperialism and Suicide". Instead she explained the violence of colonialism and then totalitarianism through historical and social conditions, ideology and philosophy. ${ }^{28}$ She still saw mass violence at the heart of modern history, but with the shift from colonial domination to European genocide its attachment to a wide set of bureaucratic practices became contingent on a wide range of factors. The 'suicidal' dimensions of nihilism were subsumed in a description of the passive masses swept up in totalitarian movements. ${ }^{29}$ Arendt retained the general category of nihilism to characterise the destructive tendencies at the core of European thought, tied to modern ways of seeing history in terms of a blend of fatalism and voluntaristic freedom. ${ }^{30}$ Its surfacing into

\footnotetext{
${ }^{25}$ Ibid., 171; For a detailed discussion of race and imperialism in Hegel's thought, see Robert Bernasconi, "With What Must the Philosophy of World History Begin? On the Racial Basis of Hegel's Eurocentrism", Nineteenth Century Contexts 22.2 (2000), 190.

${ }^{26}$ Arendt, Human Condition, 139-44; For a discussion of these themes, see Owens, Between War and Politics, 135-36; Kenneth Frampton, "The Status of Man and the Status of His Objects: A Reading of the Human Condition", in Hannah Arendt: The Recovery of the Public World, ed. Melvyn A. Hill (New York, 1979).

${ }^{27}$ For discussions of Arendt's notion of barbarism, see Canovan, A Reinterpretation, 22, 32-38, $102-$ 110 .

${ }^{28}$ See for example Hannah Arendt, "The Image of Hell”, in Essays in Understanding, 1930-1954: Formation, Exile, and Totalitarianism, ed. Jerome Kohn (New York, 2005), 203-04.

${ }^{29}$ Arendt's change of emphasis was indicative of a background of radical appropriations of mass society discourse. Émigré contemporaries such as Theodor Adorno, Max Horkheimer and Erich Fromm were making similar claims about the roots of fascism during the same period. See Theodor $\mathrm{W}$ Adorno and Max Horkheimer, Philosophische Fragmente (New York, 1944); Max Horkheimer, Eclipse of Reason (Oxford, 1947); Erich Fromm, The Fear of Freedom (London, 1942); In 1936 in Paris she had joined a discussion group of intellectuals associated with the Frankfurt School. See Marrus, "Hannah Arendt and the Dreyfus Affair", 148.

${ }^{30}$ For an exploration of this theme, see Canovan, A Reinterpretation, 11-14.
} 
the mainstream of Western history marked a radical break with history. The philosophical basis for this treatment can be discerned in her early criticisms of French existential thought.

\section{NIHILISM AND EXISTENTIALISM}

French existentialism, Arendt opined, was a "rebellion of the intellectuals" hostile to bourgeois society and committed to a notion of freedom not bound to historical forces. ${ }^{31}$ In a 1946 piece she commended Sartre's lecture "Existentialism is a Humanism", delivered in 1945, for rejecting both the "sterility of the old revolutionary elite" and the "spiritual bankruptcy of the left". Alluding to attempts to clear a political and intellectual space between the Socialist Party (SFIO) and the French Communist Party (PCF), she was also praising Sartre's humanistic rejection of materialism and emphasis on the contingency of existence. ${ }^{32}$ Nevertheless, she suggested that his "new humanism" was a reinvigorated nihilism. ${ }^{33}$ Her usage of 'nihilism' in this instance followed Heidegger's emphasis on the obscuring of Being by the stress placed on individual beings in Western metaphysics. Heidegger saw Descartes's dualism as exemplary of this forgetting, in its strict division of subjectivity from world and consequent treatment of man and his surroundings through the prism of self-consciousness. ${ }^{34}$ In his play The Flies (1944), she noted,

\footnotetext{
${ }^{31}$ Hannah Arendt, "French Existentialism", in Essays in Understanding, 1930-1954: Formation, Exile, and Totalitarianism, ed. Jerome Kohn (New York, 2005) 192-93; Arendt viewed bourgeois society as partly responsible for the rise of totalitarianism. One reviewer of Origins commented that "For Miss Arendt, it is the bourgeoisie, as a class...that has become radically evil..." Philip Rieff, "The Theology of Politics: Reflections on Totalitarianism as the Burden of Our Time (a Review Article)", The Journal of Religion 32.2 (1952), 119; Arendt had met Sartre in New York in 1945, having already crossed paths with him in Paris during the 1930s. Young-Bruehl, Hannah Arendt, 117.

${ }^{32}$ Arendt, "French Existentialism", 192-3, 188-9; Her attitude reflected a conviction that continental political parties had proved impotent in the face of fascism. See Arendt, Origins, 89-120, 261-3; For more on the political context for "Existentialism is a Humanism" see Edward Baring, "Humanist Pretensions: Catholics, Communists, and Sartre's Struggle for Existentialism in Postwar France", Modern Intellectual History 7.3 (2010), 581-609.

${ }^{33}$ A chapter from Nausea appeared in the same issue of Partisan Review in which Arendt's piece was published, under the title "The Root of the Chestnut Tree". Arendt, "French Existentialism", 189; In his lecture, Sartre had rejected materialisms that led "one to treat every man including oneself... as a set of pre-determined reactions". Jean-Paul Sartre, Existentialism and Humanism, ed. Philip Mairet trans. Philip Mairet (London, 1948), 45.

${ }^{34}$ Heidegger's most influential discussion of nihilism was presented in his lectures on Nietzsche from the 1930s. However, Arendt's critical discussion of "nihilation" and Being as nothingness in "What is Existential Philosophy?" in 1946 suggests his inaugural lecture at the University of Freiburg "What is Metaphysics", which she would have had easier access to, was more prominent in her mind. Martin Heidegger, Nietzsche: Nihilism, ed. David Farrell Krell trans. Frank A. Capuzzi (London, 1982) IV; Martin Heidegger, "What is Metaphysics?", in Pathmarks, ed. William McNeill (Cambridge, 1998), 82-96; Heidegger, Nietzsche: Nihilism, 97; Michael Allen Gillespie, Hegel, Heidegger, and the Ground of History (Chicago, 1984), xiv-xv, 20; Bogdan Costea and Kostas Amiridis, "The Movement of
} 
Sartre proposed that "if man becomes aware of his own consciousness... he realises that he depends upon nothing and nobody outside himself". ${ }^{35}$ The suggestion was that by conflating existence with subjective consciousness, Sartrean existentialism entailed a nihilistic relationship to others and a hubristic account of human capacities. ${ }^{36}$

The appeal of this form of nihilism in France, Arendt believed, was a reaction to the spread of devoluntarising philosophies of history. In "What is Existential Philosophy?" (1946) the same year as her review of French existentialism, she argued that radical and nihilistic accounts of human freedom were best understood as responses to the determinism of modern historical consciousness. ${ }^{37}$ Her argument rested on a compressed history of alienation and historicism in post-Kantian German thought. The problem of historicism, she claimed, emerged in the nineteenth century alongside the increasing influence of the natural sciences on the humanities, leading to the underplaying of human agency through definitions of human agency in terms of the "historical or natural or biological or psychological flow in which he [man] was caught up" ${ }^{38}$ During the same period, she argued, the notion of alienation emerged as a philosophical problem, rooted in the Kantian split between the noumenal realm of rational freedom and the phenomenal world of causal determinism. In nineteenthcentury philosophy this led to attempts to overcome alienation and determinism in the name of human freedom. Increasingly radical anthropocentric idealisms and materialisms - such as that of Marx - masked the persistence of "an open or hidden concept of fate" combined with an "element of defiance". 39

Nihilism as Self-Assertion", in The Movement of Nihilism: Heidegger's Thinking After Nietzsche, ed. Laurence Paul Hemming and Kostas Amiridis and Bogdan Costea (London, 2011), 14-16.

${ }^{35}$ Arendt, "French Existentialism", 193.

${ }^{36}$ This was also an implication of Heidegger's critical response to Sartre, first published in France in early 1947. Martin Heidegger, "Letter on Humanism", in Basic Writings, ed. David Farrell Krell (San Francisco, 1993); See Anson Rabinbach, "Heidegger's 'Letter on Humanism' as Text and Event”, in In the Shadow of Catastrophe: German Intellectuals Between Apocalypse and Enlightenment, ed. Anson Rabinbach (New York, 1995), 97-129; Ethan Kleinberg, Generation Existential: Heidegger's Philosophy in France, 1927-1961 (Ithaca, NY, 2005), 11-12; Gillespie, Hegel, Heidegger, and the Ground of History, 124-25.

${ }^{37}$ Hannah Arendt, "What is Existential Philosophy?", in Essays in Understanding, 1930-1954: Formation, Exile, and Totalitarianism, ed. Jerome Kohn (New York, 2005).

${ }^{38}$ Ibid., 166; In Origins Arendt stated that "organic naturalistic definitions of peoples" were an "outstanding characteristic" of German historicism. Arendt, Origins, 166; Arendt did not use "historicism" to refer only the institutionalised German academic discourses normally associated with the term - she collected Hegel and theorists of decline such as Oswald Spengler under the rubric - her usage fits into a pattern of misappropriations by émigrés in the 1940s seeking to explain Nazism and Stalinism, Karl Popper being the most prominent example. See Karl R Popper, The Open Society and Its Enemies: Vol I - the Spell of Plato, 1st edn. (London, 1945) I.

${ }^{39}$ Arendt, "What is Existential Philosophy?", 171. 
Early phenomenology, Arendt claimed, sought to circumvent this choice between freedom and necessity by reconstituting the world through human consciousness. ${ }^{40}$ This entailed treating man as a "world-creating being", capable of constructing a totalising philosophical system that would end alienation. By conferring divine status on humanity, this endeavour both failed to recognise its historical conditions secularisation - and remained trapped in a Cartesianism it had intended to surpass. ${ }^{41}$ Though Heidegger's drew attention to the impossibility of this project, in the process he produced a radical nihilism by placing nothingness at the heart of Being to create a "world-destroying being". ${ }^{42}$ Arendt maintained that despite his claims to have effected a destruction of Western metaphysics, Heidegger was still beholden to Cartesian ontology that posited a rigid divide between consciousness and supposedly external phenomena. Her narrative of philosophical change had a sharp political point. While avoiding denigrating existentialism entirely, Arendt sought to criticise the irresponsibility of Heidegger's thought, and its adaptation by Sartre, spurred on by additional information about Heidegger's involvement with Nazism, Arendt sought to criticise the irresponsibility of his thought. ${ }^{43}$ Cartesian ontology, reflecting a wider metaphysics of modernity, tended to separate being from a wholly externalised, fallen and alienated world, leading to an unworldly and instrumental attitude to politics. Given his conviction that public speech was idle chatter and political life irredeemable, it was unsurprising, she argued, that Heidegger's radicalisation of this tendency led him to the destructive panacea of National Socialism. ${ }^{44}$ This nihilistic combination of Cartesianism, phenomenology and existentialism, she suggested, was being radicalised by Sartre and other French thinkers. ${ }^{45}$

\footnotetext{
${ }^{40}$ Husserl was the key figure she referred to. Arendt, "What is Existential Philosophy?", 165; For an excellent survey of Husserl and early phenomenology, see Dermot Moran, Edmund Husserl: Founder of Phenomenology (2005).

${ }^{41}$ Arendt, "What is Existential Philosophy?", 166; For more on the issue of secularisation in Arendt's thought, see Samuel Moyn, "Hannah Arendt on the Secular", New German Critique 35.3 (2008), 71 96; Elizabeth Brient, "Hans Blumenberg and Hannah Arendt on the "Unworldly Worldliness" of the Modern Age", Journal of the History of Ideas 61.3 (2000), 513-30.

42 Arendt, "What is Existential Philosophy?", 177.

${ }^{43}$ Ibid. n.2, 187.; Arendt praised Karl Jaspers's existential theory of "communication" as an alternative to Heidegger's philosophy, ibid., 174.

${ }^{44}$ Arendt, "What is Existential Philosophy?", n2, 187.

${ }^{45}$ Arendt was referring to Sartre's Being and Nothingness (1943). Sartre had used Henri Corbin's translations of Heidegger, which translated Heidegger's Dasein in somewhat anthropocentric and individualist terms as réalité-humaine Jean-Paul Sartre, Being and Nothingness: An Essay on Phenomenological Ontology, ed. M. Warnock trans. Hazel E. Barnes (London, 1943); See Kleinberg, Generation Existential, 124, 70, 112-14; Stefanos Geroulanos, An Atheism That is Not Humanist Emerges in French Thought (Stanford, CA, 2010), 53; Rabinbach, 'Heidegger's 'Letter on Humanism' as Text and Event".
} 
The existentialist model of freedom opposed to historically-imposed necessity generated conceptions of politics and the past that placed violence at the heart of historical change, as the only means of breaking with the dead weight of the past or the mediocrity of mass society. This violent relationship between freedom and necessity, Arendt suggested, was characteristic of philosophical modernity. ${ }^{46}$ In Origins she tied this historical understanding to totalitarian ideologies: comprehensive Spenglerian or dialectical materialist notions of history had fuelled the fatalistic and relentless activism of the 'front generation'. ${ }^{47}$ Against these approaches, she argued that responsible political action would require combining sensitivity to history with discrimination. After completing the manuscript for Origins in 1949, she began to grapple with ways of approaching the past that were attuned to the need for understanding as well as responsible political engagement. Arising from an attempt to come to terms with Heidegger's involvement with Nazism, her notion of reconciliation brought personal, political and philosophical concerns to bear on historical understanding.

\section{RECONCILIATION AND UNDERSTANDING}

The occasion for Arendt's development of ideas of reconciliation and nonreconciliation as a means of judging the past was a discussion of forgiveness with with Heidegger, following their rapprochement after a visit she paid to him in February 1950, while working for the Committee for Jewish Reconstruction in Europe. Their ensuing correspondence prompted her to reflect on the themes of forgiveness, revenge, and reconciliation. Writing to her in May, Heidegger had referred to Nietzsche's thoughts from Also Sprach Zarathustra on the desire for revenge and the difficulty of reconciliation. ${ }^{48}$ In a long note written in June 1950 - the first entry of her Denktagebuch, a notebook she would maintain until 1973 - Arendt opposed reconciliation to both forgiveness and revenge, articulating a notion of judgment oriented towards the past. ${ }^{49}$ Forgiveness, she claimed, placed the judge so far above the object or person being forgiven that it meant "no further relationship"

\footnotetext{
${ }^{46}$ Arendt, Origins, 327-31, 442.

${ }^{47}$ Ibid., 331.

${ }^{48}$ Letter, Martin Heidegger to Hannah Arendt (May 6, 1950) in Ursula Ludz (ed.) Letters: 1925-1975, Hannah Arendt \& Martin Heidegger, trans. Andrew Shields (San Diego, 2004), 85.

${ }^{49}$ Hannah Arendt, Denktagebuch: 1950 - 1973, vol. 1 (Munich, 2002), 5-7; For commentary on this, see Berkowitz, "Bearing Logs on Our Shoulders: Reconciliation, Non-Reconciliation, and the Building of a Common World".
} 
was possible. It was only possible for God. She could not, therefore, ease Heidegger's burden of guilt by forgiving him. Revenge, however, was also inappropriate, as it equated judge and wrongdoer. Reconciliation, however, generated a form of solidarity resting on an acceptance of wrongs as a feature of the world, without erasing their historical occurrence through forgiveness or justifying degrading acts of revenge.

Arendt saw this notion of reconciliation - originally conceived to encapsulate her feelings about Heidegger - as suitable for affirming plurality, or human difference and unity, in the wake of catastrophe. Simultaneously past and future-oriented, reconciliation could re-establish solidarity in the wake of an abhorrent act or event. It was therefore essential to the discriminating continuation, abandonment or reformation of joint political projects. Non-reconciliation, on the other hand, provided a response to acts that could be neither forgiven nor punished, or "about which one ought...to neither be silent about or pass by", rejecting the conditions that gave rise to them, and demanding new circumstances. ${ }^{50}$ More so than forgiveness or revenge, the principles of reconciliation and non-reconciliation provided a reliable guide to judging the past.

In a subsequent and rare methodological discussion, Arendt outlined a mode of historical cognition that could ground this idea of reconciliation. Her January 1953 'Reply' to criticisms of her historical method made by philosopher Eric Voegelin was a significant step in her development of a notion of historical judgment. Her retrospective justification for the structure and approach she took in Origins, elucidated her demand for non-reconciliation to a world harbouring totalitarianism, suggesting how reconciliation and non-reconciliation might be applied to historical and political phenomena. ${ }^{51}$ Abhorrence of totalitarianism, she claimed, had led her to depart from scholarly conventions of neutrality in Origins, allowing the historical object to shape the relation between historian and object and cultivate a judgment. ${ }^{52}$ In describing "a methodological necessity closely connected with my particular subject matter", she claimed, she was not merely emphasising the difficulty of neutrality

\footnotetext{
${ }^{50}$ Arendt, Denktagebuch, 7.

${ }^{51}$ This refusal was encapsulated in her claim that totalitarianism presented a "radical evil" that could not be understood through conventional moral categories Arendt, Origins, 459; Hannah Arendt, "[The Origins of Totalitarianism]: A Reply", The Review of Politics 15.1 (1953), 78; Young-Bruehl, Hannah Arendt, 261.

${ }^{52}$ For the phenomenological aspects of Arendt's approach to politics, see Ernst Vollrath, "Hannah Arendt and the Method of Political Thinking", Social Research 44.1 (1977), 160-82; Lewis P. Hinchman and Sandra K Hinchman, "In Heidegger's Shadow: Hannah Arendt's Phenomenological Humanism”, The Review of Politics 46.2 (1984), 183-211.
} 
towards totalitarianism, but making a claim about the relationship between political judgment and historical analysis. ${ }^{53}$ Unreconciled to totalitarianism, she sought to disaggregate it into "elements" in order to destroy its conceptual unity. ${ }^{54}$

While presenting her approach as without precedent, driven by the rupture with the past caused by totalitarianism, Arendt's presentation of the role of the historical observer was clearly influenced by Walter Benjamin's “Theses on the Philosophy of History", the manuscript of which he had entrusted to her care before his suicide in $1940 .{ }^{55}$ She argued for an erosion of the separation between historian and historical object, a distinction that she claimed suppressed the stakes of historical investigation. The aim was not for "a history of totalitarianism" but rather "an analysis in terms of history", employing the "imagination consciously as tool of cognition". 56 This was an echo of Benjamin's demand that the historical materialist "blast a specific era out of the homogenous course of history". 57

Arendt's claims about imagination and cognition pointed to her respect for the mode of imaginative identification with historical objects found in German historiography. ${ }^{58}$ But by noting that "mere observation of chronological order", was "necessarily salvation and frequently justification", she was repeating Benjamin's criticisms of the quasi-theological grounds of German historicism, which he argued depicted "the sequence of events like the beads or a rosary". ${ }^{59}$ Historicism did not interpret the distinctiveness of particular events and their significance for the present; this was a claim she had previously made about Hegel's attitude towards the past. ${ }^{60}$

\footnotetext{
${ }^{53}$ Arendt, "[The Origins of Totalitarianism]: A Reply”, 78.

${ }^{54}$ Ibid., 81.

${ }^{55}$ Benjamin's "Theses" would later be published in a volume introduced and edited by Arendt. See Hannah Arendt (ed.), Illuminations: Essays and Reflections (New York, 1968); For Benjamin's influence on Arendt in general, see Ned Curthoys, "Hannah Arendt and the Politics of Narrative", Journal of Narrative Theory 32.3 (2002), 348-70; Kai Evers, "The Holes of Oblivion: Arendt and Benjamin on Storytelling in the Age of Totalitarian Destruction”, Telos (132) (2005), 109-20; Herzog, "Illuminating Inheritance: Benjamin's Influence on Arendt's Political Storytelling".

${ }^{56}$ Arendt, "[The Origins of Totalitarianism]: A Reply", 78.

${ }^{57}$ Walter Benjamin, "Theses on the Philosophy of History", in Illuminations: Essays and Reflections, ed. Hannah Arendt (New York, 1968), 263.

${ }^{58}$ In a short review of an introduction to Wilhelm Dilthey in 1945, Arendt had cautiously praised the method of empathetic projection found in German idealist historiography. Hannah Arendt, "Dilthey as Philosopher and Historian", in Essays in Understanding, 1930-1954: Formation, Exile, and Totalitarianism, ed. Jerome Kohn (New York, 2005), 137; For German historical practice in the early twentieth century, see Charles R Bambach, Heidegger, Dilthey and the Crisis of Historicism (Ithaca; London, 1995); George G Iggers, "Historicism: The History and Meaning of the Term", Journal of the History of Ideas 56.1 (1995), 129-52; Colin T Loader, "German Historicism and Its Crisis", The Journal of Modern History 48.3 (1976), 85-119.

${ }_{59}$ Arendt, "[The Origins of Totalitarianism]: A Reply", 77

${ }^{60}$ Arendt, "What is Existential Philosophy?", 164.
} 
Contemporary historicism, she suggested, viewed the emergence of totalitarianism in terms of "intellectual affinities and influences". ${ }^{61}$ This hinted at the approaches of contemporaries Jacob Talmon and Karl Popper, but also to Voegelin's own reading of totalitarianism. ${ }^{62}$ In contrast, the role of the historian, Arendt implied, was to observe disparate strands and historical objects and assemble them into something resembling what Benjamin referred to as "the constellation which his own era has formed with a definite earlier one". ${ }^{63}$ In Origins she had assembled the elements that were to "crystallize into totalitarianism". ${ }^{64}$ Such an approach required judgment grounded by either reconciliation or non-reconciliation.

The tentative claims Arendt presented in her reply to Voegelin did not, however, constitute a methodology. She hinted at a more systematic frame for historical investigations in "Understanding and Politics" (1954). There she defined understanding as the means by which "we come to terms with and reconcile ourselves to reality, that is, try to be at home in the world". Distinct from "correct information and scientific knowledge", it grounded political judgment, rooted in the reconciliation or non-reconciliation of historical objects. ${ }^{65}$ While "understanding" defined the relation of the historian to the historical object, "events", delimited the character of phenomena to be studied. Congealed clusters of speech and action, events were manifestations of intersubjective human freedom. Without their disruptions, history was merely "the dead monotony of sameness, unfolded in time". Events could not be explained by causal historical analysis or subsumed into wider historical processes, as they transcended "the sum total of all willed intentions and the significance of all origins". 66 The influence of Benjamin was again evident here; in her description of the "dead monotony" of history understood as a chain of causal sequences, Arendt echoed his criticisms of conceptions of history as the site of "homogenous, empty time" rather than time filled by "the presence of the now" ${ }^{67}$ She was articulating an avowedly present-oriented relationship to the past. Her conceptualisation of "events"

\footnotetext{
${ }^{61}$ Arendt, "[The Origins of Totalitarianism]: A Reply", 80.

${ }^{62}$ Voegelin had a piece on the intellectual origins of Marxism published in Review of Politics three years before. Eric Voegelin, "The Formation of the Marxian Revolutionary Idea", The Review of Politics 12.3 (1950), 275-302.

${ }^{63}$ Arendt, "[The Origins of Totalitarianism]: A Reply", 81; Benjamin, "Theses on the Philosophy of History", 263.

${ }^{64}$ Arendt, "[The Origins of Totalitarianism]: A Reply", 81.

${ }^{65}$ Arendt, "Understanding and Politics", 307.

${ }^{66}$ Ibid., 320; For more on Arendt's “events", see Seyla Benhabib, "Introduction”, in Politics in Dark Times: Encounters With Hannah Arendt, ed. Seyla Benhabib (Cambridge, 2010), 5.

${ }^{67}$ Arendt, "Understanding and Politics", 320; Benjamin, "Theses on the Philosophy of History", 261.
} 
also resembled Benjamin's claim about the historical materialist approaching “a historical subject only where he encounters it as a monad". 68

While the description provided of the historical gaze drew on Benjamin, Arendt's argument rested on a more clearly non-Marxist basis, attuned to a notion of reconciliation as a form of judgment. ${ }^{69}$ Seeing the past in terms of "events" was a prophylactic against the alienation fostered by the meaningless temporality prevalent in mass societies, but it was also a goad to political judgment and action, bounded by reconciliation to certain objects, and non-reconciliation to others. The chief example of an event she used was that of totalitarian domination. ${ }^{70}$ Such an event could not be assimilated into the flow of historical processes that integrated it into some higher meaning; it made prevalent forms of historical-political understanding seem obsolete. It also signified a moment of non-reconciliation. This notion of the 'event' was a rebuke to Hegel's form of universal reconciliation and to Marx's conception of history as the development of the labouring process. Both denuded history of meaning and undermined its value as a ground for action, and for an understanding that would allow one to become "at home in the world", rather than condemned to the "rootlessness" that totalitarianism had preyed upon. Arendt worked out the substance of these criticisms in "Totalitarian Elements of Marxism", an important stage in her treatment of the relationship between history, violence and action.

\section{CRITIQUING MARX}

Arendt began work in earnest on "Totalitarian Elements of Marxism" around the same time as she began to think about the notion of reconciliation. Marx, whom she read above all as providing a philosophy of history that legitimated violent transformation, was a vital foil to her views on the proper relationship between political thought and history. Yet though planned as an exploration of the Marxist road to Stalinist totalitarianism, "Totalitarian Elements of Marxism" was originally also intended to be a reconciliation of sorts, in order to benefit from Marx's insights into modern history. This entailed re-appropriating of his thought from anti-Stalinist

\footnotetext{
${ }^{68}$ Benjamin, "Theses on the Philosophy of History", 263.

${ }^{69}$ Annabel Herzog has suggested that Arendt's reluctance to draw on Benjamin explicitly was due to her assessment of him as fundamentally "apolitical”. Herzog, "Illuminating Inheritance: Benjamin's Influence on Arendt's Political Storytelling”, 20; It was likely just as much to do with the Marxist aspects of his "Theses". For more on Benjamin's Marxism, see Michael Löwy, Fire Alarm: Reading Walter Benjamin's on the Concept of History, trans. Chris Turner (2005), 17-106.

${ }^{70}$ Arendt, "Understanding and Politics", 308.
} 
intellectuals. ${ }^{71}$ Looking for trans-Atlantic and European intellectual solidarity in the late 1940s, she had become disenchanted with the bellicosity of American antiStalinism. ${ }^{72}$ It was in this context that she announced to her friend and erstwhile mentor Karl Jaspers that she intended to study Marx, at a time when "every little idiot thinks he has a right and a duty to look down" on him. ${ }^{73}$ Even as late as 1952, Arendt remained more sympathetic than many of her émigré contemporaries, writing that Marxism had "done as much to hide and obliterate the actual teachings of Marx as it has to propagate them". ${ }^{74}$

Marx, Arendt argued, was vital to understanding modern history, not only as the progenitor of a radical intellectual tradition that had been used to legitimise Soviet totalitarianism, but also as an acute observer of the rise of labour as a political force. ${ }^{75}$ Lecturing on totalitarianism in universities across Europe after the publication of Origins in March 1951, she had the opportunity to delve into Parisian archives on the history of the labour and socialist movements. Following another trip to Paris in 1952, she prepared a series of lectures on "Karl Marx and the Tradition of Western Political Thought" delivered at Princeton in $1953 .^{76}$ These lectures indicate that she had begun to use Marx's political economy to clarify her views of the global developments that had led to totalitarianism. In Origins she had described the masses uprooted from class interests, breaking with class analyses, while retaining a Marxist emphasis on imperialism. ${ }^{77}$ Now she extended her narrative chronologically and thematically with the aid of his account of primitive accumulation from the first volume of Capital,

\footnotetext{
${ }^{71}$ Hannah Arendt, "From Hegel to Marx", in The Promise of Politics, ed. Jerome Kohn (New York, 2005), 75; Arendt to H.A. Moe, 29 Jan. 1953, LOC/Washington, Box 22, 012641; For a detailed summary of Arendt's plans for "Totalitarian Elements of Marxism", see Canovan, A Reinterpretation, 63-99.

${ }^{72}$ In June 1949 Arendt wrote to Jaspers noting that if an American intellectual was "at odds with Sartre, whom he can't fit into the formulae Stalinist versus anti-Stalinist" he would invariably declare that Sartre was "a reluctant Stalinist". Sartre was attempting at the time, with little success, to establish a 'third way' between the United States and the Soviet Union through a democratic socialist anti-war grouping named Rassemblement Démocratique Révolutionnaire (RDR). Hannah Arendt to Karl Jaspers, 3 June 1949, Lotte Köhler and Hans Saner (eds.) Hannah Arendt and Karl Jaspers: Correspondence: 1926-1969, trans. Rita and Robert Kimber (New York, 1992), 136-37; Isaac, Arendt, Camus, 181-82; James D Wilkinson, The Intellectual Resistance in Europe (Cambridge, MA, 1981), 101-02.

${ }^{73}$ Arendt to Karl Jaspers, 3 June 1949, 137.

${ }^{74}$ Hannah Arendt, "Karl Marx and the Tradition of Western Political Thought", Social Research 69.2 (2002), 275; See for example J.L Talmon, The Origins of Totalitarian Democracy (London, 1951); J.L. Talmon, Utopianism and Politics (University of Michigan, 1957); Karl R Popper, The Open Society and its Enemies: Vol II - The High Tide of Prophecy: Hegel, Marx and the Aftermath (London, 1947), 2.

${ }^{75}$ Arendt, "Karl Marx and the Tradition of Western Political Thought", 277.

${ }^{76}$ See Canovan, A Reinterpretation, 63-98.

${ }^{77}$ Arendt, Origins, 145; See also Arendt, "Expansion and the Philosophy of Power".
} 
combining his accounts of Reformation-era expropriations of communal land and the Industrial Revolution to explain the emergence of 'mass societies' dependent on economic growth at the expense of the public spheres required to support political life. $^{78}$

Arendt's interest was less in Marx's political economy, however, than in his philosophy of history, against which she began to define her own mode of historical understanding. While respecting his acumen as a critic of capitalism, she argued that he possessed a deterministic conception of history modelled on the activity of labour itself. The future emancipation of labour would allow the mastery of nature to produce 'the truly human world on earth'. ${ }^{79}$ But labour, Arendt argued, was the most repetitive and ultimately meaningless of human activities. By cheering the 'gigantic multiplication of needs, the fulfilment of which is felt to belong to the necessities of life', Marx inadvertently urged on the development of the stultifying mass societies described in Origins, now redefined in terms of nihilistic and 'worldless' devotion to labouring and consuming. ${ }^{80}$ Arendt's view of Marx's notion of labour as biologised was not a freestanding phenomenological analysis, but reflected the influence of postwar French readings that imputed Hegelian and phenomenological categories to Marx's thought. ${ }^{81}$

In the late 1940s, a focus on alienation and the revolutionary humanising of the world in Marx's thought had become central to a humanist form of Marxism directed against crude forms of dialectical materialism associated with Stalinism. ${ }^{82}$ MerleauPonty, for example, wrote in Humanism and Terror (1947) that "it has been remarked without paradox that Capital is a concrete Phenomenology of Mind, that is to say, that it is inseparably concerned with the working of the economy and the realization of man". ${ }^{83}$ The "whole import of Marxist politics", he argued, could not be understood

\footnotetext{
${ }^{78}$ Arendt, "Karl Marx and the Tradition", 284-91; Hannah Arendt, "Ideology and Terror: a Novel Form of Government", The Review of Politics 15.3 (1953), 323-24; This account was the backdrop to her later political philosophy. See, for example Arendt, Human Condition, xiii-xiv; For Arendt's emphasis on the Reformation as a foundational moment for modernity, see 66, 248; See also Hannah Arendt, "Society and Culture", Daedalus 89.2 (1960), 281-82; Arendt, "Tradition and the Modern Age"; Arendt, On Revolution, 22-23, 62-3, 121; For Marx's account of primitive accumulation, see Karl Marx, Capital Vol. 1: A Critique of Political Economy, ed. Friedrich Engels, (London, 1992), 873-940.

${ }^{79}$ Hannah Arendt, "From Hegel to Marx", in The Promise of Politics, ed. Jerome Kohn (New York, 2005), 79-80.

${ }^{80}$ Arendt, "Karl Marx and the Tradition", 311.

${ }^{81}$ For a useful overview of this trend, see Poster, Existentialist Marxism, 42, 51, 59.

${ }^{82}$ Ibid.

${ }^{83}$ Maurice Merleau-Ponty, Humanisme et Terreur: essai sur le problème communiste (Paris, 1947), 101.
} 
without "going back to Hegel's description of the fundamental relations between men". ${ }^{84}$ Arendt's approach at the beginning of "Totalitarian Elements of Marxism" was similar. In February 1951, before her studies of labour in Paris, she still viewed Marx in a primarily humanist vein; justifying her plans to a sceptical Jaspers, she pointed to his early article "Debates on the Law on Thefts of Wood", and its rebellion against the "abstraction of society" and the "de-humanizing of man and the denaturizing of nature" by the "economy of commodities". ${ }^{85}$ By the end of the year, however, she had moderated this emphasis on Marx's humanism. Invoking a phenomenological contrast bolstered by readings in Parisian archives on labour and socialism, she claimed in her Guggenheim application that he conflated humanising work - associated with craft and artistry - with labour, a repetitive, dehumanising interaction with nature geared towards the reproduction of life. ${ }^{86}$

Arendt's critique of Marx's philosophy of history relied on a strong distinction between labour and work. Yet as critics have pointed out, Marx did not draw such a strong distinction between the two activities. Instead, following Hegel, he emphasised their dialectical relation, ascribing humanising potential to labour in ways that Arendt seemed to wilfully ignore. ${ }^{87}$ Making her case for the separation of labour and work, she drew on Engels, Darwin, and her own phenomenological interpretation, stressing the similarity between Marx's view of labour and natural scientific history. ${ }^{88}$ Her combination of the Hegelian and humanist Marx of the Economic and Philosophical Manuscripts with the purportedly economistic one of Capital brought together early and late writings at a time when other commentators were beginning to stress their

\footnotetext{
${ }^{84}$ Ibid.

${ }^{85}$ Letter, Arendt to Jaspers (March 4, 1951), Correspondence, 168; Karl Marx, and Friedrich Engels, Marx-Engels Gesamtausgabe, Vol. I, (Berlin, 1932), 266.

${ }^{86}$ Hannah Arendt, "Project: Totalitarian Elements in Marxism" (1951), LOC/Washington, Box 64; Arendt, "Karl Marx and the Tradition", 283-286, 309; Hannah Arendt, "Socrates", in The Promise of Politics, ed. Jerome Kohn (New York, 2005), 37-38; Arendt drew especially on the section 'Independence and dependence of self-consciousness: Lordship and Bondage' in GWF Hegel, Phenomenology of Spirit (Oxford, 1977), 111-119;

${ }^{87}$ For a highly critical Marxist response to Arendt's reading in The Human Condition, see WA Suchting, "Marx and Hannah Arendt's The Human Condition", Ethics 73.1 (1962): 47-55; See also Jay, "The Political Existentialism of Hannah Arendt", 245-47; Parekh, "Hannah Arendt's Critique of Marx".

${ }^{88}$ Hannah Arendt, "Religion and Politics", in Essays in Understanding, 1930-1954: Formation, Exile, and Totalitarianism, ed. Jerome Kohn (New York, 2005), 377; For Arendt's take on Engels's 'scientific' interpretation of Marx, see Hannah Arendt, "The Great Tradition I. Law and Power", Social Research 74.3 (2007), 720; The texts Arendt drew on were Karl Marx and Engels Friedrich, "Socialism: Utopian and Scientific", in Selected Works, ed. Clemens Palme Dutt and Vladimir Viktorovich Adoratskiı̌ (New York, 1936); Friedrich Engels, Anti-Dühring: Herr Eugen Dühring's Revolution in Science (New York, 1935).
} 
difference. ${ }^{89}$ Arendt suggested that neither a simply humanist, nor a simply determinist interpretation of Marx was possible, because he persistently combined the necessity of labour with the radical freedom to remake the world through humanising work. It is notable that she would acknowledge in The Human Condition (1958) that there was little textual basis in his writings for her distinction. ${ }^{90}$ She held on to her questionable distinction between labour and work in order to present Marx as the culmination of a modern tendency to see human existence in terms of a radical opposition between necessity and freedom. This was the metaphysical relationship she had criticised in "What is Existential Philosophy?".

In his conception of the past, Arendt argued, Marx granted history meaning only through a "single gigantic development process" that reduced it to data read off the historical ledger. This flattened interpretative complexity and prevented the past from becoming a source of understanding that would allow reconciliation to the world. ${ }^{91}$ Worse, in treating violence as "the midwife of history", he furnished the basis for doctrines of dialectical materialism that legitimated violence as a tool for escaping from historical necessity to the realm of freedom, reaching a nadir with the Stalinist belief that terror would speed historical progress. ${ }^{92}$ Marx's form of historical understanding, Arendt claimed, encouraged not only an indiscriminate reconciliation to the past, but specifically to its violence, thus inhibiting the exercise of political judgment essential to a proper form of reconciliation that could make individuals at home in the world. This interpretation is best understood alongside her view of contemporary French thought.

\section{WORK, VIOLENCE AND HISTORY}

Postwar French thought suggested to Arendt that even existentialist approaches to Marxism advocated reconciliation to the purported necessity of violence. Her stays in Paris in 1951 and 1952 solidified her view of the renewed influence of Hegel and Marx amongst French intellectuals. ${ }^{93}$ Her criticisms were tempered, however, by respect for the political and philosophical attitude of French existentialism. She also remained unwilling to imply crude causal connections between Marxian ideas and

\footnotetext{
${ }^{89}$ Poster, Existentialist Marxism, 57-71.

${ }^{90}$ Arendt, Human Condition, 79-80.

${ }^{91}$ Arendt, "Religion and Politics", 376.

${ }^{92}$ Arendt, "Understanding and Politics", 287.

${ }^{93}$ Young-Bruehl, Hannah Arendt, 281.
} 
Soviet totalitarianism. Nevertheless, disillusioned with her intellectual acquaintances, by 1954 she was willing to criticise them openly. Opposition towards reconciliation to violence and the 'progressive or doomed course of history' became one of the foci of her tentative concept of historical understanding ${ }^{94}$

Like many European thinkers after the Second World War, Arendt found notions of the progressive direction of history deeply unpalatable. ${ }^{95}$ Writing with a sense that traditional concepts of state and international relations were breaking down, she hoped for progress towards Kant's vision of perpetual peace through a postwar European federation, but had no faith in history leading to a cosmopolitan endpoint. ${ }^{96}$ She also entertained the possibility that an 'end of history' might succeed in bringing about mass societies devoid of a public realm, especially in light of Nazi and Soviet success in organising great masses of individuals along race or class lines. ${ }^{97}$ She was deeply critical of non-pluralistic conceptions of groups, nations or worse, humanity, acting as collective subjects in history. ${ }^{98}$

Arendt explored the intellectual and political origins of conceptions of historicallydeveloping humanity from the earliest stages of 'Totalitarian Elements of Marxism'. Both Hegel and Marx, she claimed in September 1951, thought that humanity rationally revealed itself by shaping the world through work. Unlike Hegel, however, Marx suggested that work could be applied to shape the course of human history, humanising the world by bringing about the emancipation of labour. ${ }^{99}$ While Hegel had restricted his view of historical understanding to "what was comprehensible in purely contemplative terms", Marx allowed conscious action to produce truth; Humanity could realise the Absolute - laws of history validated by dialectical

\footnotetext{
${ }^{94}$ Arendt, "Understanding and Politics", 322.

${ }^{95}$ For Arendt's views on progress in the context of Jewish history, see Hannah Arendt, "The Moral of History", in The Jewish Writings, ed. Jerome Kohn and Ron H Feldman (New York, 2007), 313-14

${ }^{96}$ In a letter to Jaspers, Arendt wrote "I cling fanatically to hope for a united Europe". Hannah Arendt to Karl Jaspers, 4 Oct. 1950, Lotte Köhler and Hans Saner (eds.) Hannah Arendt and Karl Jaspers: Correspondence: 1926-1969, trans. Rita and Robert Kimber (New York, 1992), 157; For Arendt's thought on international relations, see Owens, Between War and Politics; See also Hannah Arendt and International Relations: Readings Across the Lines, eds. Anthony F. Lang Jr and John Williams (New York, 2005); For Kant's cosmopolitanism see Immanuel Kant, "Perpetual Peace", in Kant: On History, ed. Lewis White Beck (Indianapolis, IN, 1963); Perpetual Peace: Essays on Kant's Cosmopolitan Ideal, eds. James Bohman and Matthias Lutz-Bachmann (Cambridge, MA, 1997).

${ }^{97}$ Arendt, Origins, 436; For a brief discussion of this, see Roy T Tsao, "Arendt and the Modern State: Variations on Hegel in the Origins of Totalitarianism", The Review of Politics 66.1 (2004), 132.

${ }^{98}$ She feared that a globally-organised humanity might choose to democratically "liquidate" certain groups. See Origins, 299.

${ }_{99}$ Arendt, "From Hegel to Marx"; Arendt, "The Impact of Marx", LOC/Washington; Arendt, "Karl Marx and the Tradition of Western Political Thought", 282-83.
} 
materialism - rather than relying on the cunning of History to do it behind their backs. ${ }^{100}$ Revolutionary change became the means by which the social organism of humanity could make history coincide with the development of productive forces. ${ }^{101}$ Such a reading was hardly unprecedented. In his Paris seminars during the 1930s, Kojève had presented a teleological and anthropocentric Hegel, filtered through German phenomenology and Marxian political economy. Human existence in his scheme was rooted in time rather than space; in intentional becoming and conscious direction. Progress was driven by man's mastery of nature, but also by a dialectic of struggles between masters and slaves, leading to a view of history as a series of violent conflicts directed towards a hopeful end. ${ }^{102}$ Kojève's interpretation of historical change was taken up and radicalised by others.

In Humanism and Terror, Merleau-Ponty had emphatically endorsed the Kojèvian association between violence and historical change. ${ }^{103} \mathrm{~A}$ former member of the Resistance and co-founder of influential journal Les Temps modernes with Sartre and Simone de Beauvoir, Merleau-Ponty discussed, through a discussion of the Moscow Trials of the 1930s, whether the use of violence and terror by the Soviet Union could be justified. The argument was complicated by the fact that it was now possible "to construct a picture of Soviet life which is the opposite of proletarian humanism". ${ }^{104}$ He concluded that violence and terror was justifiable if it brought history to an end and created "humanity"; a totality of non-exploitative relations between human beings. Denial of the need for violence was to be complicit with its institutionalisation in capitalist exploitation and imperialism, the practical manifestations of liberal humanism. Violence was already basic to politics, "the common origin of all regimes". ${ }^{105}$ The question was not "to know whether one accepts or rejects violence", but whether the form one allied with was progressive, tending "toward its own

\footnotetext{
${ }^{100}$ Arendt, "From Hegel to Marx", 76; For the 'cunning of reason' see G.W.F Hegel, Lectures on the Philosophy of World History: Introduction, Reason in History, ed. Duncan Forbes, trans. H.B. Nisbet (Cambridge, 1975), 89; For a discussion of the relationship between reason and history in Hegel see Charles Taylor, Hegel (Cambridge, 1977), 389-428.

${ }^{101}$ Arendt, "From Hegel to Marx", 76.

${ }^{102}$ Alexandre Kojève, Introduction to the Reading of Hegel: Lectures on the Phenomenology of Spirit, ed. Allan Bloom trans. James H. Nichols (Ithaca, NY, 1969). 3-7; Ethan Kleinberg has examined Kojève's reading of Hegel in the context of the development of French existential philosophy. See Kleinberg, Generation Existential, 57, 74, 79.

${ }^{103}$ Humanisme et Terreur comprised of essays published between 1946 and 1947 in Les Tempes modernes. See Taylor Carman, Merleau-Ponty (New York, 2008), 152; For discussions of the philosophical context see Geroulanos, An Atheism, 215-79; Rabinbach, "Heidegger's 'Letter on Humanism' as Text and Event", 121; Poster, Existentialist Marxism, 159.

${ }^{104}$ Carman, Merleau-Ponty, 161-62; Merleau-Ponty, Humanism and Terror, 153.

${ }^{105}$ Merleau-Ponty, Humanisme et Terreur, 109.
} 
suspension or toward self-perpetuation". ${ }^{106}$ The basis of human life in relations of domination and struggles for recognition meant that history had to be understood in terms of violence, justified on the basis of its eventual cessation. History was, Merleau-Ponty argued in Kojèvian-Hegelian terms, "essentially a struggle - the struggle of the master and the slave, the struggle between classes". This was, he claimed, "a necessity of the human condition". 107

Arendt sought to undermine such understandings of history as a violent process amenable to conscious control. Perhaps the earliest expression of this endeavour was "Ideology and Terror: A Novel Form of Government", later turned into the final chapter of the second edition of Origins (1958). ${ }^{108}$ Delivered in its earliest form as a lecture entitled 'Ideology and Propaganda' at Notre Dame in 1950, the version published in The Review of Politics in 1953 downplayed the role of totalitarian propaganda, which she had stressed in the first edition of Origins, instead emphasising the power of ideologies: deductive, spuriously logical systems disconnected from reality, genuinely believed by their adherents. ${ }^{109}$ This was not the definition of ideology used by Marx or the Frankfurt School. The content of an ideology, she argued, was less important than the consistency of its argumentative structure. ${ }^{110}$ The political and theoretical gulf between her concept and that of Marxists was highlighted by her use of dialectical materialism as an exemplar of ideology, assimilating historical data according to a "stringent logicality" and justifying the use of terror to force the course of human history to fit it. ${ }^{111}$

The model of totalitarian ideology that Arendt presented in her 1953 article contained a potted version of her interpretation of Marxian labour and work. The contentless core of ideologies was balanced by the work-like understanding of history they fostered. In driving attempts to mould the plural and unpredictable human world to fit teleological design, ideologies encouraged the escalation of violence. The Bolsheviks had thought it possible to make history and achieve a classless society

\footnotetext{
${ }^{106}$ Ibid., 1 .

${ }^{107}$ Ibid., 102.

${ }^{108}$ First published in 1953, "Ideology and Terror" was added to the first German edition of Origins (1955), and then to the second English-language edition published in 1957. For a discussion of the piece and its relation to Origins, see Tsao, "The Three Phases of Arendt's Theory of Totalitarianism". 604-12.

${ }^{109}$ Arendt, "Ideology and Terror", 326-27.

${ }^{110}$ For Marx's account of ideology, see Karl Marx and Friedrich Engels, The German Ideology, ed. C.J Arthur (London, 2004); For a study of the Frankfurt School's varied uses of ideology, see Raymond Geuss, The Idea of a Critical Theory: Habermas and the Frankfurt School (Cambridge, 1981).

${ }^{111}$ Arendt, "Ideology and Terror: A Novel Form of Government", 318.
} 
through conscious planning. But the experience of work - such as the making of a table necessarily involving the killing of a tree - could not be applied to unpredictable 'political activity, action, or historical events, or any other interaction between man and man' without becoming destructive. ${ }^{112}$ She extended this claim to argue that categories of instrumentality applied to politics were inherently self-defeating, leading to means becoming ends. This was the form of self-negating nihilism she had critiqued in imperial expansion for the sake of expansion. Terror used to hasten the creation of Humanity simply resulted in more terror to whip recalcitrant individuals and groups into line, leading to the creation of new enemies to satisfy the ideal of continual transformation itself. The most brutal examples of the Sisyphean impossibility of applying instrumental standards of work to politics, she argued, were the anti-utilitarian frenzies of the Nazi genocide and the Soviet purges. ${ }^{113}$ Stalinist dialectical materialism was a parody of Marx's historical teleology, combining the violence of work with the self-perpetuating character of labour. ${ }^{114}$

This form of self-justifying violence was also present, Arendt argued, in legitimations of American foreign policy in terms of its historical destiny as leader of the free world. Attempts to turn democracy into a "cause" frequently entailed supporting "tyrannies and dictatorships, or misery and shameless exploitation of man by man, or the imperialist type of oppression of foreign peoples". ${ }^{115}$ That such policies were often encouraged by ex-Communists suggested to her that modern approaches to history shared a particular ideological form. ${ }^{116}$ Though they had recanted their previous beliefs, they had not "lost their faith in History and its bloody and grandiose demands upon mankind". ${ }^{117}$ In later criticisms of the Vietnam War, she would combine these criticisms with a reiteration of her "boomerang thesis" from Origins. ${ }^{118}$ Her arguments also lay in stark contrast to those presented by Merleau-

\footnotetext{
${ }^{112}$ Hannah Arendt, "The Eggs Speak Up”, in Essays in Understanding, 1930-1954: Formation, Exile, and Totalitarianism, ed. Jerome Kohn (New York, 2005), 283.

${ }^{113}$ Hannah Arendt, "Mankind and Terror", in Essays in Understanding, 1930-1954: Formation, Exile, and Totalitarianism, ed. Jerome Kohn (New York, 2005) 302-3; Hannah Arendt, "The ExCommunists", in Essays in Understanding, 1930-1954: Formation, Exile, and Totalitarianism, ed. Jerome Kohn (New York, 2005), 394-96.

${ }^{114}$ Arendt, "Ideology and Terror: A Novel Form of Government", 318, 322-3.

${ }^{115}$ Hannah Arendt, "The Aftermath of Nazi Rule: Report From Germany", in Essays in Understanding, 1930-1954: Formation, Exile, and Totalitarianism, ed. Jerome Kohn (New York, 2005), 271.

${ }^{116}$ She used the example of the American Communist and Soviet spy turned anti-Communist, Whittaker Chambers. Arendt, "The Ex-Communists", 392.

117 Arendt, "The Eggs Speak Up", 278.

${ }^{118}$ Arendt, "Home to Roost"; Hannah Arendt, "Lying in Politics", in Crises of the Republic (New York, 1972), 18, 45-6.
} 
Ponty, who had accepted violence in the hope that it would be self-limiting, guaranteed by reason in history, presupposing "in the present and in the flow of events a totality moving toward a privileged state which gives the whole its meaning". 119

Arendt employed her critique of Marxian labour and work, forged in Paris but applied to American politics, to criticise the increasingly Hegelian and Marxist politics of the French existentialists. In the process, she returned to the treatment of nihilism, necessity and freedom from 'What is Existential Philosophy?'. In Paris during the spring of 1952, she described to her husband how Sartre, the existential philosopher Eric Weil and others were "wrapped up in their theories", living "in a world Hegelianly organized". ${ }^{120}$ She had the opportunity to articulate these criticisms in a paper entitled "Concern with Politics in Recent European Philosophical Thought", which she presented at the September 1954 meeting of the American Political Science Association. She discussed European responses to totalitarianism, pointing especially to two strains of postwar French existentialism.

The first, represented by Camus and André Malraux, was committed to a limited revolt against social conditions, marked by an absence of "historical system or an elabourate definition of ends and means". ${ }^{121}$ The second, exemplified by Sartre and Merleau-Ponty, superimposed Marx as a "frame of reference" on a revolutionary commitment to action, even though "their original impulses owed hardly anything" to Marx. ${ }^{122}$ The stakes of this claim were rooted in the public dispute that unfolded in 1952 between Sartre and Camus over The Rebel (1951), but reached back to the positions Merleau-Ponty had taken in Humanism and Terror. The apparently Manichean choice between global capitalism and communism that appeared to French intellectuals had led Sartre to support Communism as the lesser of two evils, and Camus to reject such a choice. ${ }^{123}$ Arendt's claim that there were two distinct strains of

\footnotetext{
${ }^{119}$ Merleau-Ponty, Humanisme et Terreur, 165, 153.

${ }^{120}$ Hannah Arendt to Heinrich Blücher, 1 May 1952, Lotte Kohler (ed.) Within Four Walls: The Correspondence Between Hannah Arendt and Heinrich Blücher, 1936-1968 (New York, 2000), 162.

${ }^{121}$ Arendt, "Concern with Politics", 438.

${ }^{122}$ Ibid., 439.

${ }^{123}$ Ronald Aronson, Camus \& Sartre: The Story of a Friendship and the Quarrel That Ended It (2004), $1-8$.
} 
French existentialism in "Concern with Politics" must be read in light of her support for Camus's position. ${ }^{124}$

Sartre and Merleau-Ponty's turn to Marxism, she argued, was driven by a refusal to be reconciled to alienation, finding it not primarily in economic relations but in the hypocrisy of bourgeois society, and in human existence, "uncertain, incoherent" and embedded in an "incomprehensible universe". ${ }^{125}$ Revolutionary action was more about endowing the world with "humanly comprehensible meaning" than changing social and economic conditions. ${ }^{126}$ The utopian character of "this attempt to save one's soul through political action" prevented it from formulating political principles and directing political choices. ${ }^{127}$ Arendt claimed that such revolutionary action was intended to allow men to dwell in an "entirely humanized, man-made reality, so that the absurdity of human life will cease to exist". But for the French existentialists, she argued, absurdity would not cease for individuals, but instead "for mankind in the midst of the human artifice". ${ }^{128}$ She argued that this slippage from the individual to an illusory collective humanity concealed the "extreme subjectivism of Cartesian philosophy" that found here "its last and most radical expression". ${ }^{129}$ This subjectivist worldlessness led to a desperation to find meaning in history, exacerbated by the brutal and seemingly meaningless events of the twentieth century. It provided ideal conditions for a renewed interest in Hegel's thought. ${ }^{130}$ She was employing a reading of Hegel developed in parallel with her critique of Marx since 1951.

Taking political phenomena seriously without abandoning a concept of transcendent truth or succumbing to overly optimistic hopes of progress, the Hegelian approach, Arendt argued, did not claim as Marx did that conscious human action could drive world-historical change. In Hegel's philosophy of history humans could not control the outcomes of their actions on such a scale, because, she noted, they

\footnotetext{
${ }^{124}$ Arendt had referred to Camus in 1946 as "the best man in Europe", with "great political insight". Hannah Arendt to Karl Jaspers, 11 Nov. 1946, Lotte Köhler and Hans Saner (eds.) Hannah Arendt and Karl Jaspers: Correspondence: 1926-1969, trans. Rita and Robert Kimber (New York, 1992), 66; In 1952 Arendt sent Camus a letter of support during the controversy over The Rebel, and in a letter to her husband, pointedly described him as "the best man now in France. He's head and shoulders above the other intellectuals". Arendt to Heinrich Blücher, 1 May 1952, 162.

${ }^{125}$ Arendt differentiated between "Marxists" concerned with alienation, and Soviet totalitarians, who sought to make man a "labouring animal" to overcome alienation. Arendt, "Concern With Politics", 438-39.

${ }^{126}$ Ibid., 438.

127 Ibid.

${ }^{128}$ Ibid., 440.

${ }^{129}$ Ibid., 437.

${ }^{130}$ Ibid., 430; For a discussion of pre-war French interest in Hegel see Michael Kelly, "Hegel in France to 1940: A Bibliographical Essay", Journal of European Studies 11(41) (1981), 29-52.
} 
could "never have reliable control over the actions they have begun and can never fully realise their original intentions". ${ }^{131}$ This view of the tragic fallibility of action, derived especially from his chapter on "Spirit" in Phenomenology of Spirit, had a significant influence on Arendt. ${ }^{132}$

She also recognised the influence of Hegel's tragic view of action on MerleauPonty. In notes taken on Humanisme et Terreur for her 1954 APSA paper, she copied out his remark that 'the nightmare of involuntary responsibility and guilt over one's position that underlay the Oedipal myth', and his approving reference to Hegel's view of Greek tragedy, which 'has beneath it this idea of a fundamental chance which renders us guilty and totally innocent, because we know not what we do'. ${ }^{133}$

However, while finding, as Merleau-Ponty did, Hegel's emphasis on the tragedy of subjective unpredictability appealing, she argued that he ultimately stripped events and deeds of their human meaning by subsuming them into a grander historical process. Twentieth-century Hegelianism had been used to support quixotic attempts to find a home for humanity amidst radical upheavals, fostering a tragic mode of reconciliation to a historical process that seemed inescapably dominated by violence. While superficially enabling for action, this determination to find meaning in violence embedded in a temporal flow was easily transformed, she suggested, into selfdefeating, instrumental and ideological treatments of history. ${ }^{134}$

The roots of the notion of history as a devoluntarising flow, Arendt argued, fundamentally lay in Hegel. He was the first, she claimed, to interpret the past as "history", rather than a series of disconnected events, recuperating meaning from history without relying on divine guarantee. ${ }^{135}$ In one of her earliest readings of Hegel, from 1951, she noted that in his thought politics only "became reconciled in history" on the assumption that history was a process, given meaning and a rationale as the means by which the World Spirit "reveals itself through the human consciousness" as a truth that transcended politics, sublimating the contingency of

\footnotetext{
${ }^{131}$ Arendt, "From Hegel to Marx", 76.

${ }^{132}$ Arendt's library at Bard College contains two heavily annotated copies of Phenomenology of Spirit, in which she places particular emphasis on the sections describing the tragic ethical conflicts found in Antigone. For a discussion of the connections between Arendt and Hegel on tragic narrative, see Allen Speight, "Arendt and Hegel on the Tragic Nature of Action", Philosophy \& Social Criticism 28.5 (2001), 523-36; See also George Kateb, Hannah Arendt, Politics, Conscience, Evil (Oxford, 1984), n.2, 44; Fine, Political Investigations.

${ }^{133}$ Hannah Arendt, 'M. Merleau-Ponty, Humanisme et Terreur' (1957), Arendt Papers, Box 83, ms. 025300.

${ }^{134}$ Arendt, "Concern With Politics", 430.

${ }^{135}$ Arendt, "Concern With Politics", 444.
} 
events into a universal dialectic driven by Providence. ${ }^{136}$ This was not reconciliation to specific "events", but rather general, tragic reconciliation to world-historical processes, leaving no space for discriminating judgment. Arendt's objection to French interpretations of Hegel and Marx's thought was not that they were too historical, but that they were not aware of the central features of their historical situation, or "historicity". ${ }^{137}$ She remarked that even when they adopted Heidegger's notion of historicity - the radical temporal structure of existence - they granted it a 'much stronger Hegelian flavour' that involved regressing to older forms of comprehensive philosophies of history exemplified by both Hegel and Marx. In the wake of totalitarianism, reconciliation to the rupture represented by Nazism and Stalinism seemed absurd. In a barb implicitly directed at Humanism and Terror, she asked how anyone could "dare to reconcile himself with the reality of extermination camps or play the game of thesis-antithesis-synthesis until his dialectics have discovered "meaning" in slave labour?". 138

For Arendt, the subsumption of cataclysmic events into a purported stream of history was characteristic of modern philosophies of history. This was not solely due to the appeal of teleological historical schemes. The search for stable frameworks of historical meaning among French thinkers had encouraged recourse to the Hegelian presentation of historical time as a constant flow. Events only acquired meaning through their place in causal relationships or grand processes. ${ }^{139}$ Rather than allowing this to generate fatalism, French had applied the Cartesian tendencies that she identified in French existentialism to argue for the possibility of radical freedom through a break with historical necessity. The result was an instrumental model of historical change, rooted in Marx's radicalisation of Hegel, placing the violence that resulted from this instrumentality at the heart of historical consciousness. The historical legitimation of violence, she suggested, lay at the heart not only of Marxism, but modern historical consciousness in general. Reconciliation to the fact of

\footnotetext{
${ }^{136}$ Arendt, "From Hegel to Marx", 76; Hegel, Lectures on the Philosophy of World History: Introduction, Reason in History, 52.

${ }^{137}$ Arendt noted that even when the French existentialists adopted Heidegger's notion of Geschichtlichkeit, or 'historicity', they granted it a "much stronger Hegelian flavour" that involved a regress to the older "modern concept of history" exemplified by Marx and Hegel. Arendt, "Concern With Politics", 433.

${ }^{138}$ Ibid., 444.

${ }^{139}$ Arendt, "[The Origins of Totalitarianism]: A Reply”, 83.
} 
violence had ultimately led to ideological justifications of terror. ${ }^{140}$ For Arendt, understanding and coming to terms with twentieth-century violence became the central task of any political mode of approaching the past.

\section{CONCLUSION}

Against the justification of violence she discerned in modern historical consciousness, in the early 1950s Arendt developed concepts of reconciliation and non-reconciliation to propose that historical method in political theory focus on fidelity to the singularity and difference of past events, rather than the purported flow of macro-historical processes. This mode of historical understanding would form the basis of her later theory of judgment. This was not a systematic historical theory, and as she acknowledged to Voegelin in 1953, she thought it difficult to translate into historical writing. Nevertheless, the extent to which she did not possess a coherent concept of history in the early 1950s should not be overstated.

There were three aspects to her historical sense: first, reconciliation and nonreconciliation as ways of conceiving of the judgment of phenomena; second, "events" as the most significant historical phenomena, and third, a hermeneutic relation to events. This form of relationship to the past would help individuals be reconciled to the world, and would ground future political action in a manner that militated against nihilistic voluntarism and revolutionary violence. Historical understanding - in addition to the aesthetic judgment she stressed in her much later Kant lectures - was an important stage in the formation of her theory of judgment. ${ }^{141}$

A key, neglected element in the development of Arendt's political theory was her critique of violence and treatment of Marxism. As the transition from Origins to "Totalitarian Elements of Marxism" shows, she shifted from a metaphysical and phenomenological argument about violence generated by nihilism to a philosophicalhistorical one emphasising its mediation through historical consciousness. What was

\footnotetext{
${ }^{140}$ Arendt, "Tradition and the Modern Age", 21; Arendt, "Karl Marx and the Tradition of Western Political Thought", 287; Arendt, "Religion and Politics", 375.

${ }^{141}$ Arendt, Lectures on Kant's Political Philosophy; See also her writings collected in Jerome Kohn (ed.), Responsibility and Judgment (New York, 2009); There is an enormous literature on Arendt's concept of judgment. See David L Marshall, "The Origin and Character of Hannah Arendt's Theory of Judgment", Political Theory 38.3 (2010), 367-93; See also Ronald Beiner and Jennifer Nedelsky, Judgment, Imagination, and Politics: Themes From Kant and Arendt (Lanham, MD, 2001); Seyla Benhabib, "Judgment and the Moral Foundations of Politics in Arendt's Thought", Political Theory 16.1 (1988), 29-51; Max Deutscher, Judgment After Arendt (Hampshire, 2007); Bryan Garsten, "The Elusiveness of Arendtian Judgment”, Social Research 74.4 (2007), 1071-1108.
} 
new in her writing was the tension between a need for historical reconciliation, and the historical reality of violence. Modern politics, she argued, was dominated by imperialism, nihilism, racism and violence. Neither these phenomena, nor the continuing existence of the elements of totalitarianism - deracination, exploitation, the superfluity of individuals - ought to be reconciled to by political actors. Yet nonreconciliation to existing circumstances seemed to preclude understanding of the past in a way that grounded responsibility rather than nihilistic voluntarism and revolutionary violence.

The tension between reconciliation and non-reconciliation to circumstances became more apparent as Arendt went beyond her theory of totalitarianism to theorise the forms of necessity that obstructed political freedom. Here she drew on Marx's thought more than has been recognised. ${ }^{142}$ Her questionable interpretation of his concept of labour as quasi-biological treated it not as an illusory category, but as a reality that conditioned individuals in mass society to pursue private interests rather than participating in politics. The intellectual context for "Totalitarian Elements of Marxism" clarifies the reasons for this. Marx's appeal across the world, she noted, was that his analysis of capitalism and concept of labour possessed a great degree of historical and anthropological truth. She engaged with him as an acute historical thinker, reading him through a lens that allowed the possibility that an "end of history" might come about, resulting in universal mass societies devoid of a public realm. This would render humans superfluous, as the "free, labourless man who is supposed to emerge after the end of history would simply have lost his most essentially human capacity". ${ }^{143}$

Arendt's reading of Marx cemented a pessimistic narrative of modernity, focused on the emergence of mass societies and pervasiveness of violence that was in some respects as determinist as his. Yet while her critique of mass society had elitist implications for her attitude toward democracy, her critique of Hegelian Marxism highlights the extent to which these commitments did not emerge from a conventional anti-totalitarian analysis of the kind presented by Karl Popper and Jacob Talmon. ${ }^{144}$ It was in fact shaped more by a more radical French intellectual milieu.

\footnotetext{
${ }^{142}$ Hanna Pitkin has pointed to a "deep tacit parallelism" between the two. Pitkin, The Attack of the Blob, 140.

${ }^{143}$ Arendt, "Karl Marx and the Tradition", 295.

${ }^{144}$ For a recent discussion of elitism in Arendt, see Hauke Brunkhorst, "Equality and Elitism in Arendt", in The Cambridge Companion to Hannah Arendt, ed. Dana Villa (Cambridge, 2000), 196.
} 
Finally, the historical dimensions of Arendt's reading of Hegel and Marx reveal her sustained interest in the relationship between modern history and violence, and its importance to her later political theory. ${ }^{145}$ In On Violence she would critique the use of violence by revolutionaries and anti-colonial movements, and its justification by Sartre and Fanon. ${ }^{146}$ But she also dealt with similar themes in On Revolution, Between Past and Future, and to a lesser extent, in The Human Condition. ${ }^{147}$ She noted that the debates over violence in the protest movements of 1968 only showed "to what an extent Hegel's concept of history dominates the thought of Marxists and non-Marxists alike". ${ }^{148}$ The origins of this critique of violence, especially in relation to Sartre's Critique of Dialectical Reason, lay in her interpretations of Hegel and Marx.

In her analyses of political authority and violence Arendt noted that modern regimes legitimised their authority with reference to the course of history, whether towards classless or merely more economically prosperous societies. ${ }^{149}$ She also noted that both communist and democratic regimes encouraged Weberian definitions of political power and authority in terms of a monopoly of legitimately exercised violence. As this essay has shown, she understood this nexus of violence and authority to be historically legitimated. Mass societies conceived of themselves moving through time according to loosely Marxian notions of quasi-naturalised historical change. She defined "events", representing the possibility of political freedom, against this flow. But as Martin Jay has noted, there were unavoidable affinities between the practice of violence and the "new beginnings" she hoped would

\footnotetext{
${ }^{145}$ Martin Jay's criticisms still stand out in this respect. See Martin Jay and Leon Botstein, "Hannah Arendt: Opposing Views" (1978); Jay's critique of Arendt on action and violence has been criticised for its emphasis on existentialism and claim that she employs a vaguely Schmittian decisionism. See Canovan, A Reinterpretation, 131.

${ }^{146}$ Arendt, On Violence, 12-13, 20-1, 89-91; See Curthoys, "The Refractory Legacy of Algerian Decolonization: Revisiting Arendt on Violence"; Elizabeth Frazer and Kimberley Hutchings, "On Politics and Violence: Arendt Contra Fanon", Contemporary Political Theory 7.1 (2008), 90-108; Breen Keith, "Violence and Power: A Critique of Hannah Arendt on 'The Political", Philosophy \& Social Criticism 33.3 (2007), 343-72.

${ }^{147}$ Arendt, On Revolution, 12-21, 84-88, 114-115; Arendt, "Tradition and the Modern Age", 22-24; Hannah Arendt, "What is Authority?", in Between Past and Future: Eight Exercises in Political Thought (New York, 2006) 102-11; Arendt, Human Condition, 263, $26-7$.

${ }^{148}$ Arendt, On Violence, 89-90.

${ }^{149}$ Hannah Arendt, "Breakdown of Authority" (lecture notes) (1953), LoC/Washington, Box 72; Hannah Arendt, "Authority in the Twentieth Century", The Review of Politics 18 (4) (1956), 403-17; Arendt, "What is Authority?"; See also Jacques Derrida, "Force of Law: The Mystical Foundation of Authority", Cardozo Law Review 11 (1990), 919; Bonnie Honig, Political Theory and the Displacement of Politics (New York, 1993).
} 
found new forms of political authority and replace rule by historically-legitimated force. ${ }^{150}$

The temporal aspects of the idealised polis Arendt would describe in The Human Condition could mitigate the problem of legitimacy; authority could be sustained through practices of remembrance and storytelling directed at founding events and political institutions, rather than repeated violent or disruptive political action. Yet remembrance and storytelling provide limited purchase on the basic tension between violence and the founding of a decent polity. Her concept of reconciliation, however, as a spur to both historical interpretation and active political judgment, suggested the possibility of an outright refusal of violent founding acts. More than remembrance or storytelling, it presented a historically-sensitive refusal, directed at political phenomena and arrangements founded on violence. Though a problematic and "monumental" historian, as Judith Shklar described her, Arendt had a concrete sense of history not only as a means of spurring action through remembrance of past noble deeds, but also as a way of cultivating, modelling, and even practicing political judgment. $^{151}$

\footnotetext{
${ }^{150}$ The slaying of Remus by Romulus in the Roman myth of founding, for example. See Jay, "The Political Existentialism of Hannah Arendt", 248.

${ }^{151}$ Judith N Shklar, "Rethinking the Past", Social Research 44.1 (1977), 80-81.
} 